Jurnal Kejuruteraan SI 1(4) 2018: 59-64

http://dx.doi.org/10.17576/jkukm-2018-si1(4)-08

\title{
Synthesis of Mesoporous Silica for Ammonia Adsorption in Aqueous Solution
}

(Sintesis Silika Mesoliang untuk Penjerapan Ammonia dalam Larutan Akues)

\author{
Rabiatul Adawiyyah Arifin”, Hassimi Abu Hasan,b*, Nur Hidayatul Nazirah Kamarudinª, Nur 'Izzati Ismail ${ }^{\mathrm{a}}$ \\ ${ }^{a}$ Chemical Engineering Programme, \\ ${ }^{b}$ Research Centre for Sustainable Process Technology (CESPRO), \\ Faculty of Engineering and Built Environment, Universiti Kebangsaan Malaysia
}

\begin{abstract}
In this work, mesoporous silica (MSN) was synthesized and tested for ammonia adsorption. The synthesized MSN was characterized using the Fourier Transform Infrared (FTIR), Scanning Electron Microscopy (SEM), Transmission Electron Microscopy (TEM), and Brunauer-Emmett-Teller (BET). In the ammonia adsorption experimental, the mass of MSN was varied at 0.5, 1.0, 1.5, 2.0 and 2. $5 \mathrm{~g}$. The data of ammonia uptake by MSN was plotted using Langmuir and Freundlich isotherms, while the kinetic adsorptions were determined using pseudo-first order and pseudo-second order kinetics. The results showed the MSN structural was hexagonal form and particle size of 70 to $150 \mathrm{~nm}$. Characterization using FTIR shows the MSN contained various chemical functional groups. The adsorption of ammonia rest resulted with a high percentage of ammonia removal. At 0.5, 1.0, 1.5, 2.0, 2.5 and $3.0 \mathrm{~g}$ of MSN, the highest adsorption uptake at 5 minutes were 0.79, 0.42, $0.31,0.21,0.17$ and $0.12 \mathrm{mg} / \mathrm{g}$, respectively. The adsorption data were fitted to the isotherm and kinetic models to predict the mechanism and kinetic characteristics of the adsorption process. The Freundlich isotherm model shows the highest correlation with the Freunclidh $\left(K_{F}\right)$ and adsorption constant ( $(n)$ of 6.78 and $0.39 \mathrm{mg} / \mathrm{g}$, respectively. For the kinetic modeling, the data of ammonia adsorption process were well fitted to the pseudo-second order with coefficient determination $\left(R^{2}\right)$ value of 0.9992. These results indicated the potential for a new application of MSN as an effective adsorbent for ammonia removal and it can be applied in the water treatment processes.
\end{abstract}

Keywords: Mesoporous silica; ammonia adsorption; water treatment; isotherms model; kinetic model

ABSTRAK

Dalam kajian ini, silika mesoliang (MSN) telah disintesis dan diuji untuk penjerapan ammonia. Pencirian terhadap MSN dilakukan dengan menggunakan Spektroskopi Transformasian Fourier Inframerah (FTIR), Mikroskop Elektron Pengimbas (SEM), Mikroskop Elektron Pancaran (TEM), dan Brunauer-Emmett-Teller (BET). Dalam uji kaji penjerapan ammonia, jisim MSN diubah pada 0.5, 1.0, 1.5, 2.0 dan 2. 5 g. Data pengambilan ammonia oleh MSN telah diplot menggunakan isoterma Langmuir dan Freundlich, sementara kinetik penjerapan telah ditentukan dengan menggunakan kinetik urutan pseudopertama dan kinetik urutan pseudo-kedua. Keputusan menunjukkan struktur MSN adalah berbentuk heksagon dengan saiz partikel antara $70-150 \mathrm{~nm}$. Pencirian melalui FTIR pula menunjukkan MSN mempunyai pelbagai kumpulan kimia berfungsi. Saiz liang MSN yang besar telah menghasilkan peratusan penyingkiran ammonia yang tinggi. Pada jisim MSN sebanyak 0.5, $1.0,1.5,2.0,2.5$ dan $3.0 \mathrm{~g}$, penjerapan ammonia tertinggi pada 5 minit pertama masing-masing adalah 0.79, 0.42, 0.31, $0.21,0.17$ and $0.12 \mathrm{mg} / \mathrm{g}$. Data penjerapan diplot pada model isoterma dan kinetik untuk meramalkan mekanisme dan ciri-ciri kinetik proses penjerapan ammonia. Model isoterma Freundlich menunjukkan korelasi tertinggi dengan pemalar Freunclidh $\left(K_{F}\right)$ dan penjerapan (n) masing-masing sebanyak 6.78 dan $0.39 \mathrm{mg} / \mathrm{g}$. Pemodelan kinetik menunjukkan data penjerapan ammonia berpadanan dengan pesanan pseudo-kedua dengan nilai penentuan koefisien $\left(R^{2}\right)$ sebanyak 0.9992. Ini menunjukkan potensi aplikasi MSN sebagai penjerap berkesan untuk penyingkiran ammonia dan boleh diaplikasikan dalam proses rawatan air.

Kata kunci: Mesoliang silika; penjerapan ammonia; rawatan air; model isoterma; model kinetik

\section{INTRODUCTION}

Water is a natural resources that very important not only for human but also for animals and plants. Water have several uses not only use for drinking but for another daily routine such as using for bath, cooking and industrial purposes (Abu Hasan et al. 2011). Nowadays, the sources for clean water remain decreasing because several resources have been polluted with the industrial effluent discharges. Failure to get a clean water for drinking will cause bad impact for long term. One of the mostly chemical compound with highly concentration presents in river water is ammonia (Ahammed \& Davra 2010) discharged by industrial activities. The Ministry of Health, Malaysia has regulated the minimum limits of ammonia that only can be presents in the treated water is not exceed $1.5 \mathrm{mg} / \mathrm{L}$ (Abu Hasan et al. 2011). 
Mesoporous silica (MSN) is an uprising adsorbent that can be used to adsorb ammonia and can be apply for water treatment. The MSN shows an excellent results and can be apply in various field such as drug delivery (Zhou et al. 2018), water purification (Karim et al. 2012; Kango et al. 2015; Nasreen et al. 2018), and carbon dioxide sequestration (Khdary et al. 2018). Eventhough, it stills new in water treatment area but this new technology shows a positive feedback. It comes with nanoparticle size of $50 \mathrm{~nm}$ to 1000 $\mathrm{nm}$. There are several advantages of MSN that can be looking for such as insoluble in water, trapped heat with high stability and high mechanical strength. The surface of MSN contains sylanol group that can be used to trap enzyme from hydroxyl, carbonyl and amino group (Sarawade et al. 2012).

The MSN also consists of surfactant that plays an essential role to form pore for adsorption process to takes place. A bigger and more pores reflect the successfully of the adsorption process. Surfactant will react differently and it depends during the synthesis process (Quang et al. 2012). The pore size can be increased by applying heat (Chen et al. 1993). The objectives of this paper are to synthesis and characterize the MSN and to determine the potential of MSN for ammonia adsorption in aqueous solution.

\section{MATERIALS AND METHODS}

Cetyltrimethylammonium bromide (CTAB), ethylene glycol (EG), ammonium hydroxide $\left(\mathrm{NH}_{4} \mathrm{OH}\right)$, ethanol $(\mathrm{EtOH})$, sodium silicate $\left(\mathrm{Na}_{2} \mathrm{O} .3 .4 \mathrm{SiO}_{2}\right)$, and sulphuric acid $\left(\mathrm{H}_{2} \mathrm{SO}_{4}\right)$ were purchased from BT Science Sdn. Bhd., Malaysia while 3-aminopropyl triethoxysilane (APTES) and tetraethyl orthosilicate (TEOS) were purchased from Merck Sdn. Bhd., Malaysia. All of the chemicals were used as received without further treatment.

\section{SYNTHESIS OF MESOPOROUS SILICA}

The method used for the MSN preparation was adopted from Kamarudin et al. (2016). About $4.68 \mathrm{~g}$ of cetyltrimethylammonium bromide (CTAB), $120 \mathrm{~mL}$ of ethylene glycol (EG) and $29 \mathrm{~mL}$ of $25 \%$ ammonium hydroxide $\left(\mathrm{NH}_{4} \mathrm{OH}\right)$ were dissolved in $720 \mathrm{~mL}$ of distilled water and was heated at $50^{\circ}$ for about 30 min with a vigorous stirring. After $30 \mathrm{~min}$, the mixer was heated to $80^{\circ}$ and then about $5.7 \mathrm{~mL}$ of tetraethyl orthosilicate (TEOS) and $1.052 \mathrm{~mL}$ of 3-aminopropyl triethoxysilane (APTES) were added to form a white suspension solution. This solution was then stirred for two hours. After that, the solution were placed inside the freezer for overnight until two phase of liquid-solid formed. The clear solution was removed and the white precipitation was centrifuged and washed using ethanol (EtOH). The synthesized MSN were dried at $110 \mathrm{o}$ and calcined at $550^{\circ}$ for 3 hours to remove the remaining surfactant.

\section{CHARACTERIZATION OF MSN}

The crystalline structure of MSN was determined by X-ray diffraction (XRD) at a ratio of $2=1.5-10$. XRD shows the present of chemical compounds in the sample. Transmission electron microscopy (TEM) was carried to observe the structural of MSN. Field-emission scanning electron microscopy (FESEM) was conducted to observe the surface morphology of the samples. Fourier Transform Infrared Spectroscopy (FTIR) was performed to identify the functional groups present in the samples. BET analysis was conducted to determine the physical characteristic of the MSN.

\section{AMMONIA ADSORPTION EXPERIMENTAL}

The different mass of MSN $(0.5 \mathrm{~g}, 1.0 \mathrm{~g}, 1.5 \mathrm{~g}, 2.0 \mathrm{~g}, 3.0$ g) was placed in the different $150 \mathrm{~mL}$ conical flask. The conical flask contains $0.5 \mathrm{~mL}$ of ammonia solution mixed with $99.5 \mathrm{~mL}$ of distilled water to represent $5 \mathrm{mg} / \mathrm{L}$ ammonia concentration. All the conical flask were closed by using aluminum foil to prevent evaporations happens. Then, all the conical flask were stirred at $150 \mathrm{rpm}$. The water was sampled at 5, 10, 15, 20 and 30 minutes. All of the samples were centrifuged and were repeated for 3 times. The ammonia concentration was analyzed using $\mathrm{HACH}$ Spectrophotometer DR3900 at a wavelength of $435 \mathrm{~nm}$. In addition, the uptake of ammonia adsorption at equilibrium, $q_{e}(\mathrm{mg} / \mathrm{g})$ was calculated as followed:

$$
q_{e}=\frac{\left(C_{o}-C_{e}\right)}{W}
$$

where $C_{o}$ and $C_{e}(\mathrm{mg} / \mathrm{L})$ are the initial and equilibrium concentration, respectively. $V$ is the volume of the solution $(\mathrm{mL})$ and $W$ is the weight of the MSN $(\mathrm{g})$.

$$
\text { ADSORPTION ISOTHERM AND KINETICS STUDIES }
$$

Adsorption isotherms characterized by certain constant values express the surface properties and affinity of the adsorbents. The adsorption isotherms of ammonia were investigated using two isotherm models: the Langmuir and Freundlich. Meanwhile, in this study, adsorption kinetics was described using the first-order equation and the pseudo second-order equation (Jeppu and Clement, 2012). The sorption kinetic provides valuable insights into the reaction pathways and the mechanism of a sorption reaction (Abu Hasan et al. 2012).

\section{RESULTS AND DISCUSSION}

\section{CHARACTERIZATION OF MESOPOROUS SILICA}

Figure 1 shows the spectra of XRD at a ratio of 1.5 to 10 . The peak that were appeared at 2.50, 4.30, and 4.95 at wavelength, $\mathrm{W}_{\mathrm{L}}$ of 1.54 . The peak appeared at 4.95 proved the formation of the mesoporous characteristic on the synthesized silica.

This peak was in good agreement with literature to prove the formation of MSN (Heikkila et al. 2010; Kamarudin et al. 2016). 
The characterization using TEM and FESEM were conducted to observe the pattern of pore surface structural, and topography of the MSN. The result from TEM analysis presents clearer images of particle as shown in Figure 2A. The TEM images shows uniformly the hexagon pattern and shape of the MSN. The MSN shape obtained in this study is similar as found by Kamarudin et al. (2016). Meanwhile, Figure $2 \mathrm{~B}$ shows the pattern structural of particles was in uniform pattern with the average sizes from 70 to $150 \mathrm{~nm}$.

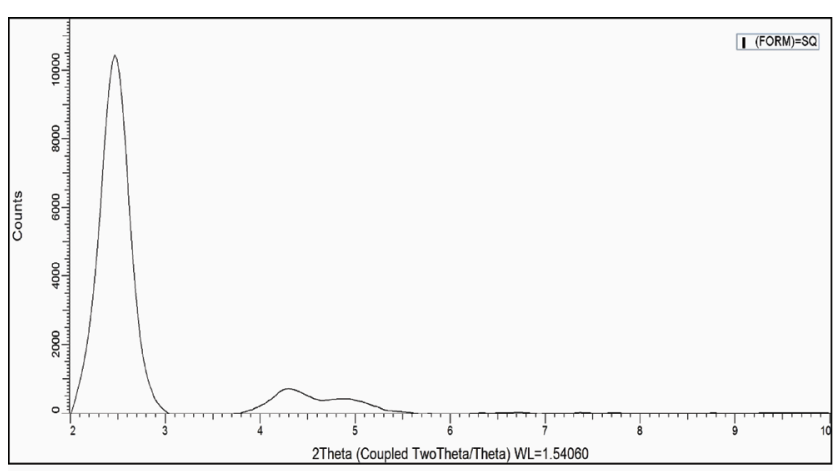

FIGURE 1. Characterization of MSN by XRD
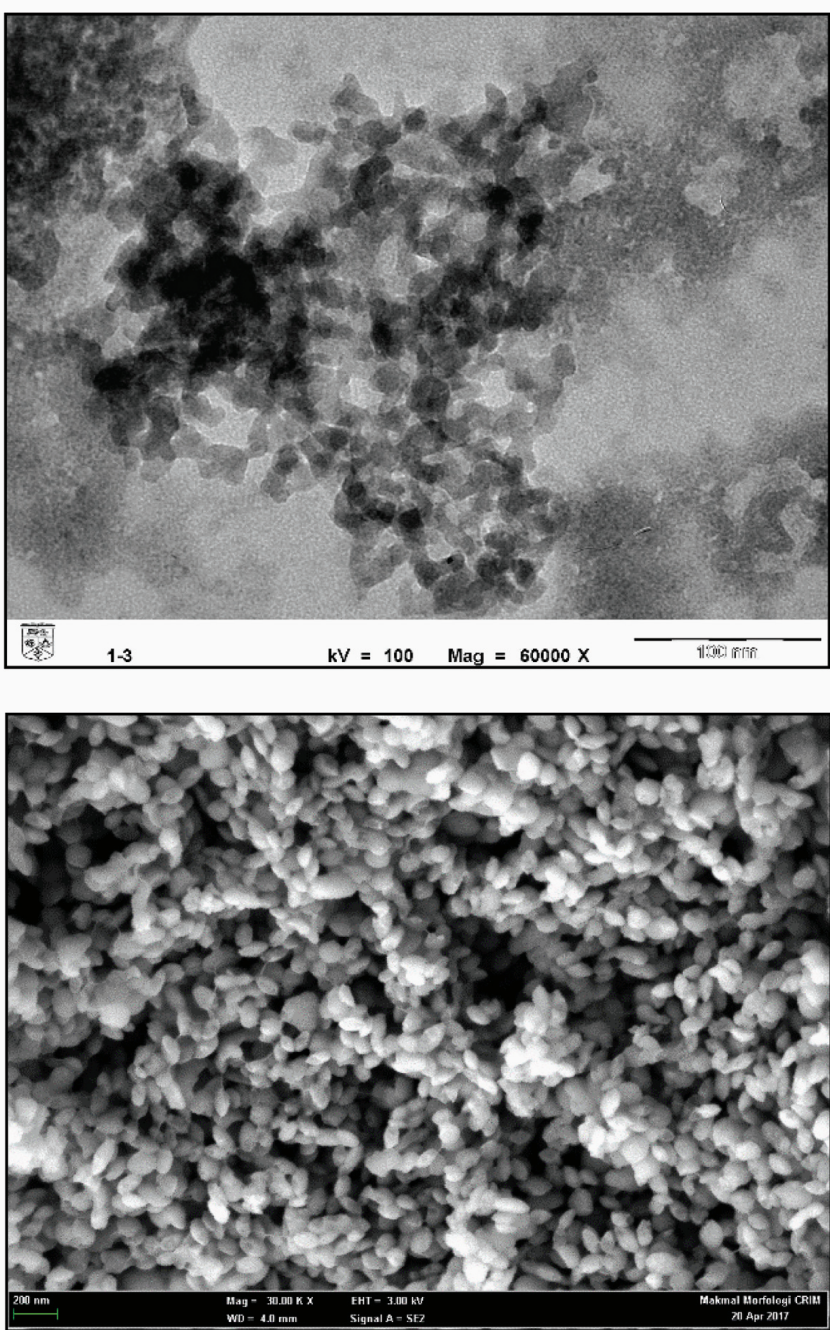

FIGURE 2. Image of MSN (A) TEM and (B) FESEM
FTIR analysis is to identify the functional group that present in the MSN sample. Figure 3 shows the different functional groups that presented in the MSN sample. The FTIR spectral exhibited IR peaks at the bands attributed to Si-O-Si bending $\left(464.7 \mathrm{~cm}^{-1}\right)$, Si-O-Si symmetric stretching $\left(857.7 \mathrm{~cm}^{-1}\right)$, external Si-OH groups $\left(895.6 \mathrm{~cm}^{-1}\right)$, Si-OSi asymmetric stretching $\left(1059.2 \mathrm{~cm}^{-1}\right)$, water molecules retained by siliceous materials $\left(1731.4 \mathrm{~cm}^{-1}\right)$ and $-\mathrm{OH}$ stretching (3010.6 $\mathrm{cm}^{-1}$, broad). The present of $\mathrm{Si}-\mathrm{O}$ on wavelength from $1000-1130 \mathrm{~cm}^{-1}$ shows the MSN itself can undergo adsorption process (Singh et al. 2011).

Moreover, $\mathrm{C}=\mathrm{C}$ aromatic and $\mathrm{C}-\mathrm{N}$ aromatic bonds were represented at wavenumber of $2127.1 \mathrm{~cm}^{-1}$ and 2000 $\mathrm{cm}^{-1}$, respectively. It shows that ammonia was successfully adsorbed by the MSN through the empty pores inside.

\section{ADSORPTION STUDY}

PERFORMANCE OF MESOPOROUS SILICA AND EFFECT OF INITIAL CONCENTRATION

Figure 4 shows the performances of ammonia removal through adsorption by MSN. It clearly shows that with 1.5 $\mathrm{g}$ of MSN resulted highly percentage of ammonia removal compared to others. At less amounts of MSN (0.5 and $1.0 \mathrm{~g})$, low removal of ammonia were due to the saturation of the MSN surface area, while at high amounts of MSN (2, 2.5 and 3.0 $\mathrm{g})$, there were frequently collision between the MSN particles during the agitation of the test, thus allowing desorption of ammonia from the MSN. From the Figure 4, it also shows that at 5 minutes, the reaction had taken place and its means that adsorption already start and resulted with a high removal percentage. At 10 to 30 minutes, the removal of ammonia decreases due to the MSN had reached the saturation state and at the meantime desorption of ammonia from the MSN occurred.

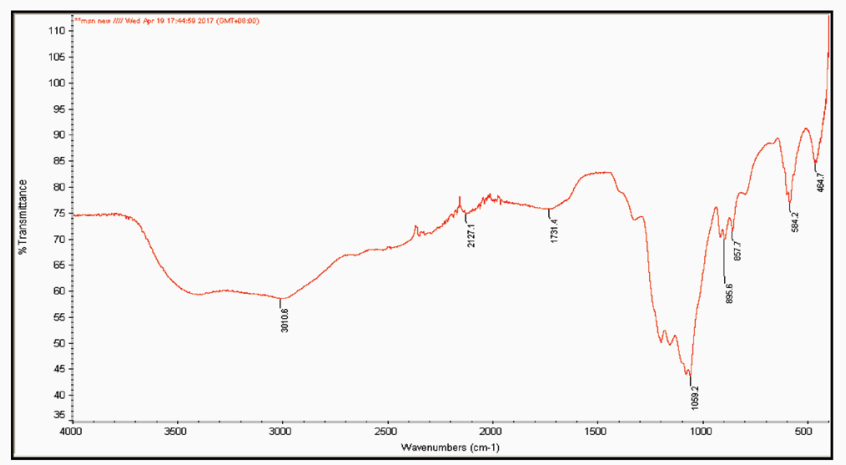

FIGURE 3. FTIR spectrum of MSN

EQUILIBRIUM ISOTHERMS STUDIES

Equilibrium isotherms is a prerequisite for prediction the adsorption uptake by the adsorbent which is the main parameter in designing an optimizing adsorption system. Two models were used in this study i.e., Langmuir and Freundlich isotherm models. Firstly, all the data were plotted 


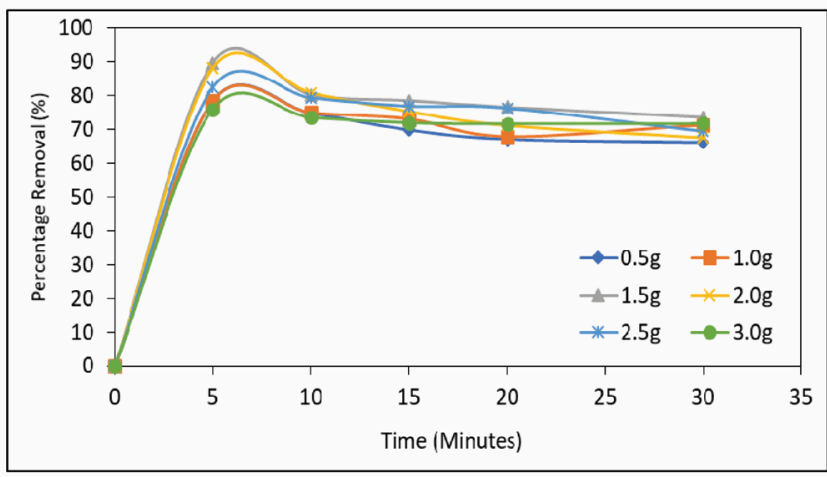

FIGURE 4. Performance of percentage removal of adsorption of ammonia

using Langmuir isotherm as shown in Equation (2) below (Dada et al. 2012):

$$
\frac{C_{e}}{q_{e}}=\frac{1}{Q_{\max } b}+\frac{C_{e}}{Q_{\max }}
$$

Where is $q_{e}$ is adsorption uptake at equilibrium conditions $(\mathrm{mg} / \mathrm{L}), Q_{\max }$ adsorption uptake at maximum adsorption, $b$ is a equilibrium constant of Langmuir, $C_{e}$ is ammonia at equilibrium time $(\mathrm{mg} / \mathrm{L})$.

Another isotherm model was Freundlich model. This model mostly suitable using for adsorption with intermediate concentration because it not follows Henry Rules [12]. The data were plotted using Freundlich isotherm as shown in Equation (3) below:

$$
\ln q_{e}=\ln K_{F}+\frac{1}{n \ln C_{e}}
$$

Where is $q_{e}$ is adsorption uptake at equilibrium conditions $(\mathrm{mg} / \mathrm{L}), K_{F}$ is a Freunclidh constant, $C_{e}$ is ammonia at equilibrium time $(\mathrm{mg} / \mathrm{L})$ and $n$ adsorption constant.

Table 1 shows the parameter constant of Langmuir dan Freundich isotherm models. From the table, the $Q_{\max }$ obtained from the Langmuir model was $99.1 \mathrm{mg} / \mathrm{g}$ while $b$ was 33.7 $\mathrm{L} / \mathrm{mg}$. In addition, from data plot using Freundlich model, it were found that the $K_{F}$ and $n$ were $6.78 \mathrm{mg} / \mathrm{g}$ and 0.39 , respectively.
TABLE 1. Adsorption isotherms constant

\begin{tabular}{ccc}
\hline Adsorption Isotherm & Constant & Values \\
\hline \multirow{2}{*}{ Langmuir } & $Q_{\max }(\mathrm{mg} / \mathrm{g})$ & 99.1 \\
\multirow{2}{*}{ Freundlich } & $b(\mathrm{~L} / \mathrm{mg})$ & 33.7 \\
& $K_{F}(\mathrm{mg} / \mathrm{g})$ & 6.78 \\
& $\mathrm{n}$ & 0.39 \\
\hline
\end{tabular}

\section{ADSORPTION KINETIC MODELLING}

The sorption kinetic provides valuable insights into the reaction pathways and the mechanism of a sorption reaction. In order to study the performance towards the adsorption ammonia, the pseudo-first order and pseudo-second order kinetic models were plotted and compared. Both kinetics were shown in Equation (4) and (5).

$$
\ln \left(q_{e}-q_{t}\right)=\ln q_{e}-k_{1} t
$$

Where $q_{e}$ is adsorption uptake at equilibrium conditions (mg/ L), $q_{t}$ is adsorption uptake toward time, and $k_{l}$ is pseudo-first order constant. Values of $q_{e}$ and $k_{1}$ can be finds by made an intercept at y-axis.

$$
\frac{t}{q_{t}}=\frac{1}{k_{2} q_{e}^{2}}+\frac{t}{q_{e}}
$$

Where $k_{2}$ is pseudo-second order constant. The values of $q_{e}$ and $k_{2}$ can be finds by made an intercept at y-axis.

From the plot, it was found that the data well fitted to the pseudo-second order kinetic (Figure 5) compared to the pseudo-first order kinetic. The correlation coefficients and other parameters are calculated from all two kinetic models and were summarized in Table 2. Kinetic model of pseudo-first order only shows low relationship with $R^{2}$ less

\begin{tabular}{|c|c|c|c|c|c|c|c|}
\hline \multirow{2}{*}{$\begin{array}{l}\text { Mass } \\
(\mathrm{g})\end{array}$} & \multirow{2}{*}{$\begin{array}{c}q_{e, \exp } \\
\left(\mathrm{mg} \mathrm{g}^{-1}\right)\end{array}$} & \multicolumn{3}{|c|}{ Pseudo-first order } & \multicolumn{3}{|c|}{ Pseudo-second order } \\
\hline & & $q_{e}\left(\mathrm{mg} \mathrm{g}^{-1}\right)$ & $k_{1}\left(\min ^{-1}\right)$ & $R^{2}$ & $q_{e}\left(\mathrm{mg} \mathrm{g}^{-1}\right)$ & $\begin{array}{c}k_{2} \\
\left(10^{-2} \mathrm{~g} \mathrm{mg}^{-1} \mathrm{~min}^{-1}\right)\end{array}$ & $R^{2}$ \\
\hline 0.5 & 655.40 & 23.26 & 0.0204 & 0.0126 & 625.00 & $-0 / 0012$ & 0.9994 \\
\hline 1.0 & 356.30 & 9.27 & -0.0027 & 0.0004 & 344.83 & -0.0034 & 0.9957 \\
\hline 1.5 & 245.13 & 11.68 & 0.0094 & 0.0043 & 238.10 & -0.0029 & 0.9964 \\
\hline 2.0 & 168.65 & 11.91 & 0.0134 & 0.0089 & 158.73 & -0.0033 & 0.9979 \\
\hline 2.5 & 138.80 & 7.83 & -0.0025 & 0.0004 & 135.14 & -0.0051 & 0.9959 \\
\hline 3.0 & 119.43 & 2.00 & 0.0206 & 0.0243 & 119.05 & -0.0784 & 0.9992 \\
\hline
\end{tabular}
than 0.60 , but the pseudo-second model presents highly value of $R^{2}$ with more than 0.99 .

TABLE 2. Values of correlation coefficients for adsorption kinetic model constant 


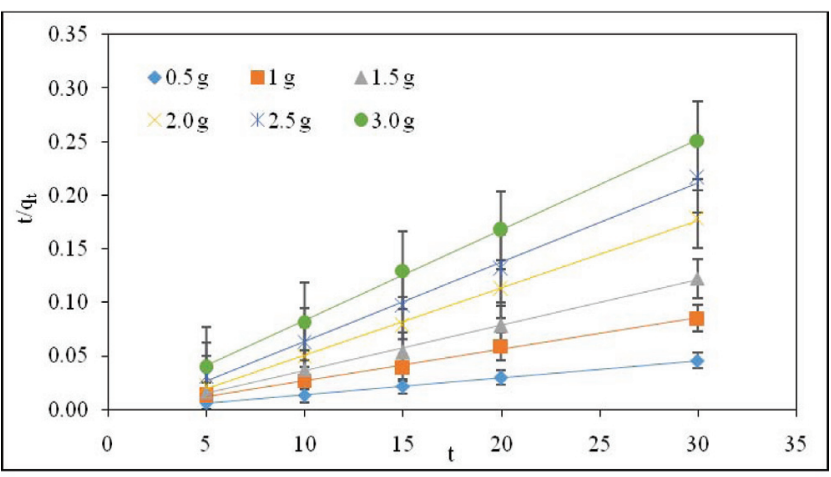

FIGURE 5. Pseudo-second order kinetic of ammonia adsorption by MSN

\section{CONCLUSION}

This work illustrates the potential of mesoporous silica (MSN) as adsorbent to adsorb ammonia from the synthetic ammonia solution. The results shows the reaction took place at first 5 minutes with higher percentage removal. The best mass of MSN for the ammonia adsorption was at $1.5 \mathrm{~g}$. Increases the mass of adsorbent did not show any good relationship to the ammonia removal percentage. The data were well fitted to the Freundlich adsorption isotherm, which reflects the multilayer adsorption. Meanwhile the best kinetic model was a pseudo-second order kinetic. The equilibrium within the 15 minutes was considered faster for the ammonia adsorption by the synthesized MSN.

\section{ACKNOWLEDGEMENT}

The author are grateful for the financial supports by from the Universiti Kebangsaan Malaysia with grant number of GUP2017-022 and the MYBrain Scholarship from the Ministry of Higher Education, Malaysia.

\section{REFERENCES}

Abu Hasan, H., Sheikh Abdullah, S.R., Kamarudin, S.K. \& Kofli, N.T. 2011. Ammonia and manganese problems in Malaysian drinking water treatment. World Applied Sciences Journal 12(10): 1890-1896.

Abu Hasan, H., Sheikh Abdullah, S.R., Kofli, N.T. \& Kamarudin, S.K. 2012. Isotherm equilibriums of $\mathrm{Mn}^{2+}$ biosorption in drinking water by local isolated Bacillus species and sewage activated sludge. Journal of Environmental Management 111: 34-43.

Ahammed, M.M. \& Davra, K. 2011. Performance evaluation of biosand filter modified with iron oxide-coated sand for house hold treatment of drinking water. Desalination 276: 287-293.

Chen, C.Y., Burkett, S.L., Li, H.L. \& Davis, M.E. 1993. Studies on mesoporous materials II. Synthesis mechanism of MCM-41. Microporous Materials 2(1): 27-34.
Dada, A., Olalekan, A., Olatunya, A. \& Dada, O. 2012. Langmuir, Freundlich, Temkin and Dubinin Radushkevich Isotherms Studies of Equilibrium Sorption of $\mathrm{Zn}^{2+}$ onto phosphoric acid modified rice husk. IOSR Journal of Applied Chemistry 3(1): 38-45.

Heikkilä, T., Santos, H.A., Kumar, N., Yu, D.M., Salonen, J., Laaksonen, T., Peltonen, L., Hirvonen, J. \& Lehto, V.P. 2010. Cytotoxicity study of ordered mesoporous silica MCM-41 and SBA-15 microparticles on Caco2 cells. European Journal of Pharmaceutics and Biopharmaceutics 74(3): 483-494.

Hilonga, A., Kim, J.K., Sarawade, P.B., Quang, D. V., Shao, G. N., Elineema, G. \& Kim, H.T. 2012a. Synthesis of mesoporous silica with superior properties suitable for green tire. Journal of Industrial and Engineering Chemistry 18: 1841-1844.

Hilonga, A., Kim, J.K., Sarawade, P. B., Quang, D.V., Shao, G.N., Elineema, G. \& Kim, H.T. 2012b. BET study of silver-doped silica based on an inexpensive method. Materials Letters 80: 168-170.

Jeppu, G.P. \& Clement, T.P. 2012. A modified LangmuirFreundlich isotherm model for simulating $\mathrm{pH}$-dependent adsorption effects. Journal of Contaminant Hydrology 129: 46-53.

Kamarudin, N.H.N., Abdul Jalil, A., Triwahyono, S. \& Timmiati, S.N. 2016. Microwave-assisted synthesis of mesoporous silica nanoparticles as a drug delivery vehicle. Malaysian Journal of Analytical Sciences 20(6): 1382-1389.

Karim, A.H., Jalil, A.A., Triwahyono, S., Sidik, S.M., Kamarudin, N.H. N., Jusoh, R. \& Hameed, B.H. 2012. Amino modified mesostructured silica nanoparticles for efficient adsorption of methylene blue. Journal of Colloid and Interface Science 386(1): 307-314.

Kango, S. \& Kumar, R. 2015. Magnetic nanoparticles coated sand for arsenic removal from drinking water. Environmental Earth Science 75(5): 381.

Khdary, N.H., Ghanem, M.A., Abdesalam, M.E. \& AlGaradah, M.M. 2018. Sequestration of $\mathrm{CO}_{2}$ using $\mathrm{Cu}$ nanoparticles supported on spherical and rod-shape mesoporous silica. Journal of Saudi Chemical Society 22: 343-351.

Nasreen, S., Urooj, A., Rafique, U. \& Ehrman, S. 2016. Functionalized mesoporous silica: absorbents for water purification. Desalination and Water Treatment 57(60): 29352-29362.

Quang, D.V., Sarawade, P.B., Hilonga, A., Kim, J.K., Shim, Y.H., Shao, G.N. \& Kim, H.T. 2012. Synthesis of silver nanoparticles within the pores of functionalized-free silica beads: The effect of pore size and porous structure. Materials Letters 68: 350-353.

Rao, K.S., El-Hami, K., Kodaki, T., Matsushige, K. \& Makino, K. 2005. A novel method for synthesis of silica nanoparticles. Journal of Colloid and Interfaces Science 289(1): 125-131.

Sarawade, P.B., Quang, D.V., Hilonga, A., Jeon, S.J. \& Kim, H.T. 2012. Synthesis and characterization of micrometer- 
sized silica aerogel nanoporous beads. Materials Letters 81: 37-40.

Singh, L.P., Agarwal, S.K., Bhattacharyya, S.K., Sharma, U. \& Ahalawat, S. 2011. Preparation of silica nanoparticles and its beneficial role in cementitious materials. Nanomaterials and Nanotechnology 1(1): 44-51.

Zhou, Y., Quan, G., Wu, Q., Zhang, X., Niu, B., Wu, B., Huang, Y., Pan, X. \& Wu, C. 2018. Mesoporous silica nanoparticles for drug and gene delivery. Acta Pharmaceutica Sinica B 8(2): 165-177.

Rabiatul Adawiyyah Arifin

Chemical Engineering Programme,

Faculty of Engineering and Built Environment,

43600 UKM Bangi, Selangor Darul Ehsan, Malaysia

*Hassimi Abu Hasan

Chemical Engineering Programme,

Research Centre for Sustainable Process Technology (CESPRO),

Faculty of Engineering and Built Environment,

Universiti Kebangsaan Malaysia,

43600 UKM Bangi, Malaysia
Nur Hidayatul Nazirah Kamarudin

Chemical Engineering Programme

Research Centre for Sustainable Process Technology (CESPRO),

Faculty of Engineering and Built Environment, 43600 UKM Bangi, Selangor Darul Ehsan, Malaysia

Nur 'Izzati Ismail

Research Centre for Sustainable Process Technology (CESPRO),

Faculty of Engineering and Built Environment,

43600 UKM Bangi, Selangor Darul Ehsan, Malaysia

*Corresponding author;

hassimi@ukm.edu.my

Received date: $6^{\text {th }}$ April 2018

Accepted date: $17^{\text {th }}$ July 2018

Online First date: $1^{\text {st }}$ October 2018

Published date: $30^{\text {th }}$ November 2018 